\title{
PENGARUH STRUKTUR MODAL, UKURAN PERUSAHAAN, RISIKO BISNIS TERHADAP NILAI PERUSAHAAN SEKTOR KIMIA YANG DI INDONESIA
}

\author{
${ }^{1}$ Chani Dinayu, ${ }^{2}$ Devi ana Sinaga, ${ }^{3}$ D.Sakuntala
}

Universitas Prima Indonesia, Medan

Email : chanidinayu01@gmail.com, devianasinaga98@gmail.com,dw1t4@yahoo.com

FIDUSIA
$\begin{gathered}\text { Jurnal Ilmiah Keuangan } \\ \text { dan Perbankan }\end{gathered}$
ISSN Cetak : 2621-2439
ISSN Online : 2621-2447
Kata Kunci : Struktur Modal,
Ukuran Perusahaan, Risiko
Bisnis, Nilai Perusahaan.

ABSTRACT
This study aims to determine the financial ratios represented by capital structure (DER), company size (ln total assets), business risk (DOL) to firm value. Data collection techniques using purposive sampling and obtained as many as 17 sample companies from 73 populations of chemical sub-sector companies listed on the Indonesia Stock Exchange (IDX) for the 2014-2018 period. The analysis model uses multiple linear regression. Based on the results of the coefficient test, the $\mathrm{R}$ square value of 0.749 shows that the correlation or closeness of the relationship of capital structure, company size, business risk and company value is only $74.9 \%$. Adjusted R Square value of 0.735 indicates that the variable capital structure, company size, and business risk explains the variable to the company value of $73.5 \%$. In the F test shows that the value of Fcount> Ftable $(53,644>2.78)$ so that simultaneously DER, ln total assets, DOL affect the value of the company in the chemical sub-sector of 2014-2018. Whereas the T-test for Company Size is 0.00 , which means it has a partial effect on Company Value. Based on these results it is recommended for investors to pay more attention to the value of DER, ln total assets, DOL before investing.

Penelitian ini bertujuan untuk mengetahui rasio keuangan yang diwakili oleh struktur modal (DER), ukuran perusahaan (In total aktiva), risiko bisnis (DOL) terhadap nilai perusahaan. Teknik pengumpulan data menggunakan purposive sampling dan didapat sebanyak 17 sampel perusahaan dari 73 populasi perusahaan sektor kimia yang terdaftar di Bursa Efek Indonesia (BEI) periode 2014-2018. Model analisis menggunakan regresi linear berganda. Berdasarkan hasil uji koefisien yang dilakukan, nilai $\mathrm{R}$ square sebesar 0.749 menunjukkan bahwa korelasi atau keeratan hubungan struktur modal, ukuran perusahaan, risiko bisnis dan nilai perusahaan hanya sebesar 74,9\%. Nilai Adjusted $\mathrm{R}$ Square sebesar 0,735 mengindikasikan bahwa variabel struktur modal, ukuran perusahaan, dan risiko bisnis menjelaskan variabel terhadap nilai perusahaan sebesar $73.5 \%$. Pada uji $\mathrm{F}$ menunjukkan bahwa nilai $\mathrm{F}_{\text {hitung }}>$ $\mathrm{F}_{\text {tabel }}(53,644>2,78)$ sehingga secara simultan DER, In total aktiva, DOL berpengaruh terhadap nilai perusahaan pada perusahaan sub sektor kimia 2014-2018. Sedangkan pada uji T Ukuran Perusahaan 0.00 yang artinya berpengaruh secara parsial terhadap Nilai Perusahaan. Berdasarkan hasil tersebut disarankan bagi investor untuk lebih memperhatikan nilai DER, In total aktiva, DOL sebelum berinvestasi.

Kata Kunci : Struktur Modal, Ukuran Perusahaan, Risiko Bisnis, Nilai Perusahaan. 


\section{PENDAHULUAN}

Dalam sejarah ekonomi Indonesia, industri kimia di Indonesia pada awalnya belum menjadi sesuatu yang penting. Hal tersebut dikarenakan banyaknya keterbatasan dari tenaga kerja, segi bahan yang dibutuhkan, dan dari segi teknologi. Sektor industri kimiasalah satunya penunjang utama dari target pertumbuhan ekonomi. Pada awal tahun 1990-an Industri kimia di Indonesia mengalami peningkatan pesat. Perkembangan pesat tersebut terjadi karena adanya penemuan baru dan teknologi yang semakin canggih. Teknik kimia juga memiliki peran penting dalam pengembangan, perancangan, dan mengkoordinasi pekerjaan pengolahan melalui proses kimia maupun fisika dengan mempertimbangkan aspek teknis relevan dan keekonomisan. Penelitian yang telah dilakukan oleh ahli kimia dapat digunakan untuk mengembangkan dan memajukan industri indonesia.

Nilai perusahaan memiliki asset berharga yang akan dibayar oleh calon pembeli apabila perusahaan tersebut sudah dijual. Nilai perusahaan merupakan penambahan jumlah ekuitas dengan hutang perusahaan. Faktor yang mencakup nilai perusahaan yaitu: struktur modal, ukuran perusahaan, keputusan investasi, kebijakan pendanaan, kebijakan deviden, dan pertumbuhan perusahaan. Dalam Nilai Perusahaan terdiri dari Price Earning Ratio (PER), Price to Book Value(PBV).

Nilai Perusahaan diukur menggunakan Price Earning Ratio (PER). Para investor menyatakan semakin tinggi PERmaka pertumbuhan laba juga akan mengalami kenaikan. Dengan begitu ratio terhadap laba akan mengalami tingkat perbandingan antara earning pershare (laba perlembar saham) dengan market price pershare (harga pasar perlembar saham).

Pada perusahaan Sektor Kimia yang terdaftar di Bursa Efek Indonesia diketahui bahwa harga saham PT Indocement Tunggal Prakarsa Tbk pada tahun 2015 senilai Rp.22.325 dan pada tahun 2016 senilai Rp.15.400 yang mengalami penurunan sebesar Rp.6.925. Harga saham PT Duta Pertiwi Nusantara Tbk pada tahun 2015 senilai Rp.387 dan pada tahun 2016 senilai Rp.400 yang mengalami kenaikan sebesar Rp.13. Harga saham PT Indal Aluminium Industry Tbk pada tahun 2015 senilai Rp.405 dan pada tahun 2016 senilai Rp.645 yang mengalami kenaikan sebesar Rp.240. Harga saham PT Champion Pacific Indonesia Tbk pada tahun 2015 senilai Rp.224 dan pada tahun 2016 senilai Rp.520 yang mengalami kenaikan sebesar Rp.296. Harga saham PT Lion Mesh Prima Tbk pada tahun 2016 senilai Rp.575 dan pada tahun 2017 senilai Rp.590 yang mengalami kenaikan sebesar Rp.15. 


\section{TINJAUAN PUSTAKA}

\section{Struktur Modal}

Struktur Modal merupakan perimbangan jumlah utang jangka pendek yang bersifat permanen, utang jangka panjang, saham preferen dan saham biasa. Tiga struktur modal yaitu: pendekatan laba bersih atau Net Income (NI) approach, pendekatan laba operasi bersih atau Net Operating Income (NOI) approach dan pendekatan tradisional.

Struktur modal telah dikembangkan khususnya untuk menganalisis pengaruh penggunaan utang terhadap nilai perusahaan dan biaya modal. (Dr.R.Agus Sartono, M.B.A, Manajemen Keuangan Teori dan Aplikasi Edisi 4, 2010)

2. Ukuran Perusahaan

Ukuran perusahaan menggambarkan besar kecilnya suatu perusahaan. Ukuran perusahaaan umumnya berpengaruh pada penilaian investor dalam membuat keputusan investasi. Secara umum, ukuran perusahaan diukur dengan besarnya total aset yang dimiliki karena nilai total asset umumnya sangat besar dibandingkan variabel keuangan lainnya. (Amalia,2015)

Besar kecilnya perusahaan (ukuran perusahaan) sangat berpengaruh terhadap struktur modal terutama berkaitan dengan kemampuan memperoleh pinjaman. Perusahaan besar memiliki kebutuhan dana yang besar untuk membiayai aktivitas perusahaan atau operasi perusahaan dan salah satu alternatif pemenuhan kebutuhan modal dengan menggunakan utang.(Regina,2015)

\section{Risiko Bisnis}

Risiko bisnis merupakan tingkat risiko dari operasi perusahaan apabila tidak menggunakan hutang. Menurut Brigham dan Houston (2011) yang dimaksud dengan risiko bisnis adalah suatu fungsi dari ketidakpastian yang inheren di dalam proyeksi pengembalian atas modal yang diinvestasikan di dalam sebuah perusahaan. Jadi, sebelum memutuskan menggunakan hutang sebaiknya manajemen perusahaan mempertimbangkan terlebih dahulu risiko bisnisnya.

Risiko bisnis juga merupakan suatu kegagalan pengawasan intern yang mengakibatkan kerugian tak terduga dan ketidakberhasilan dari manajemen untuk memastikan pengembalian kepada perusahaan.(Ida Ayu, 2016) 
4. Nilai Perusahaan

Memaksimalkan nilai perusahaan sangat penting bagi perusahaan, karena dengan memaksimalkan nilai perusahaan berarti juga memaksimalkan kemakmuran pemegang saham yang merupakan hal penting yang harus dicapai oleh manajemen perusahaan. Memaksimalkan kemakmuran pemegang saham dapat diterjemahkan menjadi memaksimalkan harga saham perusahaan. Meskipun perusahaan memiliki tujuan-tujuan yang lain, namun memaksimalkan harga saham adalah tujuan yang paling penting.Nilai perusahaan dapat diukur dengan menggunakan beberapa rasio antara lain Earning per Share(EPS) merupakan rasio yang menunjukkan berapa besar keuntungan (return) yang diperoleh investor atau pemegang saham per lembar saham, Price Earning Ratio(PER) yang merupakan rasio harga saham suatu perusahaan dengan pendapatan per saham perusahaan tersebut, Dividend Yieldyaitu perbandingan dividen dengan harga saham, dan Price to Book Value(PBV) yang merupakan rasio yang membandingkan antara nilai saham menurut pasar dengan harga saham berdasar harga buku atau book value. (Ida Ayu,2016)

\section{METODE PENELITIAN}

\section{Populasi dan Sampel}

Populasi pada penelitian ini adalah Perusahaan Sektor Kimia yang terdaftar di Bursa Efek Indonesia periode 2014 - 2018 sebanyak 73 perusahaan. Penarikan sampel menggunakan teknik purposive sampling. Purposive sampling adalah memilih sampel dari suatu populasi berdasarkan pertimbangan tertentu, baik pertimbangan ahli maupun pertimbangan ilmiah. Dari kriteria tersebut, didapat sampel sebanyak 17 perusahaan dengan periode waktu 5 tahun, sehingga jumlah data sebanyak 85 data.

\section{Definisi Operasional Variabel}

\section{a. Variabel Dependen}

\section{Teori Nilai Perusahaan}

Nilai Perusahaan merupakan harga yang tersedia di bayar kepada calon pembeli saat perusahaan tersebut dijual. Nilai perusahaan dapat dilihat dari nilai ekuitasnya. Husnan (2013:5)

$$
\mathrm{PER}=\frac{M P S}{E P S}
$$




\section{b. Variabel Independen}

\section{Struktur Modal}

Joel G. Siegel dan Jae K Sim mengatakan capital structure (struktur modal) adalah komposisi saham biasa, saham preferen, dan berbagai kelas seperti itu, laba yang ditahan, dan hutang jangka panjang yang dipertahankan oleh kesatuan usaha dalam mandanai aktiva. (Fahmi, 2011:106).

Sehingga dapat dimengerti bahwa struktur modal merupakan gambaran dari bentuk proporsi finansial perusahaan yaitu antara modal yang dimiliki yang bersumber dari hutang jangka panjang (long term liabilities) dan modal sendiri (shareholder's equity) yang menjadi sumber pembiayaan suatu perusahaan. Dan ini dipertegas oleh Jones bahwa struktur modal suatu suatu perusahaan terdiri long term debt dan shareholder's equity, dimana stockholder equity terdiri dari preferred stock dan common equity, dan common equity itu sendiri adalah terdiri dari commond stock dan retained earnings. (Fahmi, 2011:106)

\section{$\frac{\text { Total Liabilities }}{\text { Stockholder's Equity }}$}

\section{Ukuran Perusahaan}

Ukuran Perusahaan suatu skala dimana dapat diklasifikasikan besar kecilnya perusahaan menurut berbagai cara antara lain dengan total asset, nilai pasar saham, dan lain lain (Prasetyorini,2013), ukuran perusahaan dianggap mampu mempengaruhi nilai perusahaan karena semakin besar ukuran perusahaan atau skala perusahaan maka akan semakin mudah bagi perusahaan dalam memperoleh sumber pendanaan, baik yang bersifat internal maupun eksternal.

Ukuran Perusahaan menggambarkan besar kecilnya suatu perusahaan yang dapat dinyatakan dengan total asset ataupun total penjualan bersih. Semakin besar total asset maupun penjualan maka semakin besar pula ukuran suatu perusahaan. Semakin besar asset maka semakin besar modal yang ditanam, sementara semakin banya penjualan maka semakin banyak juga perputaran uang dalam perusahaan.(Hery, S.E., M.Si., CRP,. RSA., CFRM., 2017:11)

$$
\text { Size }=\text { Ln of Total Aktiva }
$$

\section{Risiko Bisnis}

Risiko Bisnis adalah potensi penyimpangan hasil korporasi (nilai perusahaan dan kekayaan pemegang saham) dan hasil keuangan karena perusahaan memasuki suatu bisnis tertentu dengan lingkungan industri yang khas dan menggunakan 
teknologi tertentu.

Risiko bisnis merupakan salah satu jenis risoko yang tidak dapat di transfer ke pihak lain. Sekali perusahaan terjun ke bisnis tertentu, maka saat itu juga perusahaan akan langsung menanggung risiko bisnis. Hal yang terpenting adalah bagaimana memastikan bahwa selera manajemen terhadap risiko tetap memeuhi prinsip semakin tinggi risiko semakin tinggi ekspektasi hasil, high risk high return.

Dengan demikian, dapat disimpulkan bahwa risiko bisnis adalah risiko yang terkait dengan posisi kompetitif perusahaan dan prospek perusahaan untuk berkembang dalam pasar yang senantiasa berubah. (Djohanputro, 2018:43)

$$
\text { degree of operating leverage }=\frac{(\text { EBIT1-EBIT0) } / \text { EBIT0 }}{(S A L E S 1-S A L E S 0) / S A L E S 0}
$$

\section{Metode Analisis}

Penelitian ini menggunakan persamaan regresi linear berganda. Yang digunakan dalam penelitian ini sebagai berikut :

$\mathrm{Y}=\mathrm{a}+\mathrm{b}_{1} \mathrm{X}_{1}+\mathrm{b}_{2} \mathrm{X}_{2}+\mathrm{b}_{3} \mathrm{X}_{3}+\mathrm{e}$

Keterangan :

$\begin{array}{ll}\mathrm{Y} & \text { : Nilai Perusahaan } \\ \mathrm{a} & : \text { Konstanta } \\ \mathrm{X}_{1} & : \text { Struktur Modal } \\ \mathrm{X}_{2} & \text { : Ukuran Perusahaan } \\ \mathrm{X}_{3} & : \text { Risiko Bisnis } \\ \mathrm{B}_{1,2} & \text { : Besaran koefisien regresi dari masing-masing variabel } \\ \mathrm{e} & \text { : error }\end{array}$

\section{PengaruhStruktur Modal terhadap Nilai Perusahaan}

Ta'dir E.Prasetia., P.Tommy., Ivone S. Saerang. 2014.Hasil Penelitian nya terdapat untuk menguji DER, Total Asset, dan Beta secara simultan berpengaruh dan signifikan terhadap Nilai Perusahaan. Hal ini dapat mengisyaratkan bahwa pihak yang terkait melihat pentingnya bagaimana kondisi struktur modal,ukuran perusahaan, dan risiko perusahaan secara bersamaan untuk mengukur nilai perusahaan.

H1: Struktur Modal secara tidak berpengaruh terhadap nilai perusahaan. 


\section{PengaruhUkuran Perusahaan terhadap Nilai Perusahaan}

I Gusti Ngurah Gede Rudangga, Gede Merta Sudiarta. 2016. Hasil penelitian nya terdapat Pengaruh Ukuran Perusahaan, Leverage, dan Profitabilitas Terhadap Nilai Perusahaan. Secara parsial ukuran perusahaan, laverage, dan profitabilitas berpengaruh positif signifikan terhadap Nilai Perusahaan. Pada perusahaan Food and Beverages yang terdaftar di BEI.

H2: Ukuran Perusahaan secara parsial berpengaruh negatif dan signifikan terhadap nilai perusahaan.

\section{PengaruhRisiko Bisnis terhadap Nilai Perusahaan}

.Ida Ayu Anggawulan Saraswathi, I Gst. Bgs. Wiksuana, Henny Rahyuda. 2016. Hasil Penelitian ini terdapat Pengaruh Risiko Bisnis, Pertumbuhan Perusahaan dan Struktur Modal terhadap Profitabilitas Serta Nilai Perusahaan Manufaktur secara simultan berpengaruh positif terhadap Profitabilitas dan Nilai Perusahaan.

H3: Risiko Bisnis secara parsial tidak berpengaruh terhadap nilai perusahaan.

\section{Kerangka Pemikiran}

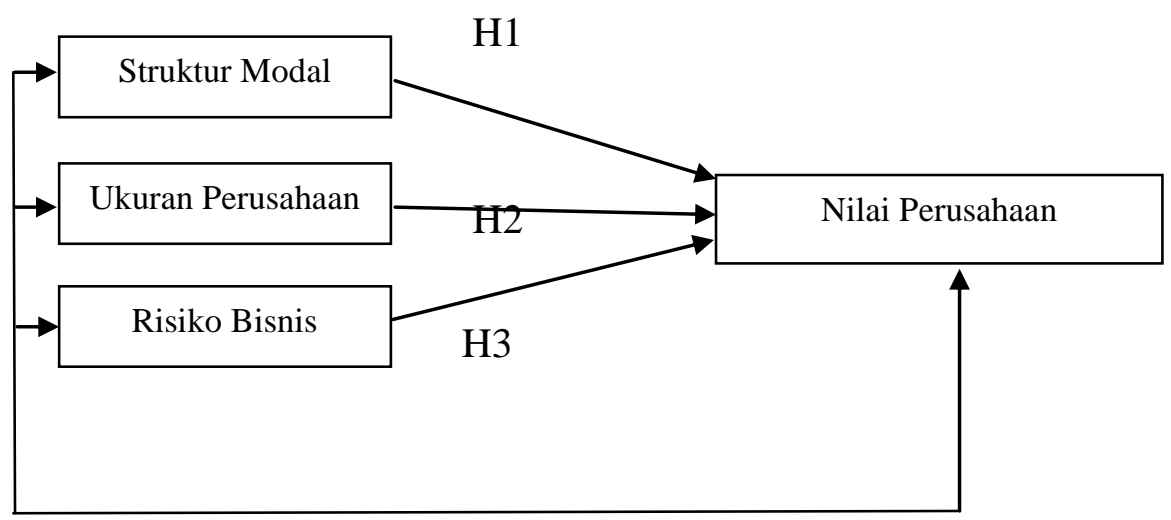

$\mathrm{H} 4$

\section{HASIL DAN PEMBAHASAN}

\section{Pengujian Hipotesis}

Hasil pengujian hipotesis dengan menggunakan Uji t yang dilakukan untuk mengetahui pengaruh antara variabel independen (Struktur Modal, Ukuran Perusahaan dan Risiko Bisnis terhadap Nilai Perusahaan)apabila nilai sig lebih kecil dari nilai signifikasi $(0,05)$ maka hipotesis diterima, sedangkan jika nilai sig lebih besar dari nilai signifikasi $(0,05)$ maka hipotesis ditolak. 
Hasil uji hipotesis menggunakan Uji t:

\section{Coefficients $^{\mathrm{a}}$}

\begin{tabular}{|c|c|c|c|c|c|c|}
\hline \multirow{2}{*}{\multicolumn{2}{|c|}{ Model }} & \multicolumn{2}{|c|}{$\begin{array}{c}\text { Unstandardized } \\
\text { Coefficients }\end{array}$} & $\begin{array}{c}\text { Standardized } \\
\text { Coefficients }\end{array}$ & \multirow[t]{2}{*}{$\mathrm{t}$} & \multirow[t]{2}{*}{ Sig. } \\
\hline & & B & Std. Error & Beta & & \\
\hline \multirow{4}{*}{1} & (Constant) & 359.275 & 28.908 & & 12.428 & .000 \\
\hline & LN_DER & .151 & .335 & .031 & .451 & .654 \\
\hline & $\begin{array}{l}\text { LN_LNT } \\
\mathrm{R}\end{array}$ & -23.278 & 1.889 & -.877 & -12.323 & .000 \\
\hline & LN_DOL & -.275 & .235 & -.082 & -1.167 & .248 \\
\hline
\end{tabular}

a. Dependent Variable: LN_PER

Hasil pengujian hipotesis, menghasilkan persamaan analisis regresi berganda berikut ini : Kebijakan Dividen = 359,275 + 0,151 (Struktur Modal)-23,278 (Ukuran Perusahaan) 0,275 (Risiko Bisnis) + e

Berdasarkan hasil pengujian hipotesis pertama, secara parsial tersebut maka dapat disimpulkan bahwa Struktur Modal tidak berpengaruh terhadap Nilai Perusahaan. Hal ini dikarenakan nilai $t_{\text {hitung }}$ lebih kecil dari $t_{\text {tabel }}(0,451<2,00488)$ dengan nilai signifikan 0,654 $>0,05$ sehingga dapat disimpulkan bahwa hasil penelitian ini berarti $\mathrm{H}_{0}$ diterima $\mathrm{H}_{\mathrm{a}}$ ditolak pada perusahaan Sub Sektor Kimia yang terdaftar di Bursa Efek Indonesia periode 20142018.

Hasil penelitian ini sejalan dengan hasil penelitian dari peneliti yang dilakukan oleh Octavia Languju, Marjam Mangantar, Hizkia H.D. Tasik (2016) yang berarti Struktur Modal secara parsial tidak berpengaruh terhadap Nilai Perusahaan.

Berdasarkan hasil pengujian hipotesis kedua, secara parsial tersebut maka dapat disimpulkan bahwa Ukuran Perusahaan berpengaruh negatif dan signifikan terhadap Nilai Perusahaan. Hal ini dikarenakan nilai $t_{\text {hitung }}$ sebesar -12,323 dan $t_{\text {tabel }} 2,00488$ atau $-t_{\text {hitung <- }}$ $\mathrm{t}_{\text {tabel }}(-12,323<-2,00488)$ dengan nilai signifikan $0,000<0,05$ sehingga dapat disimpulkan bahwa hasil penelitian ini berarti $\mathrm{H}_{0}$ ditolak $\mathrm{H}_{\mathrm{a}}$ diterima pada perusahaan Sub Sektor Kimia yang terdaftar di Bursa Efek Indonesia periode 2014-2018.

Hasil penelitian ini sejalan dengan hasil penelitian dari peneliti yang dilakukan oleh Mawar Sharon R. Pantow, Sri Murni, Irvan Trang (2015) yang berarti Ukuran Perusahaan secara parsial berpengaruh negatif dan signifikan terhadap Nilai Perusahaan.

Berdasarkan hasil pengujian hipotesis ketiga, secara parsial tersebut maka dapat disimpulkan bahwa Risiko Bisnis tidak berpengaruh terhadap Nilai Perusahaan. Hal ini dikarenakan nilai $t_{\text {hitung }}$ sebesar $-1,167$ dan $t_{\text {tabel }} 2,00488$ atau $-t_{\text {hitung }}>-t_{\text {tabel }}(-1,167>-$ 2,00488) dengan nilai signifikan 0,248>0,05 sehingga dapat disimpulkan bahwa hasil penelitian ini berarti $\mathrm{H}_{0}$ diterima $\mathrm{H}_{\mathrm{a}}$ ditolak pada perusahaan Sub Sektor Kimia yang terdaftar di Bursa Efek Indonesia periode 2014-2018. 
Hasil penelitian ini sejalan dengan hasil penelitian dari peneliti yang dilakukan oleh Regina Rumondor, Maryam Mangantar, Jacky S.B Sumarauw(2015) yang berarti Risiko Bisnis secara parsial tidak berpengaruh terhadap Nilai Perusahaan.

\section{KESIMPULAN}

Secara simultan Struktur Modal, Ukuran Perusahaan, Risiko Bisnis berpengaruh positif terhadap nilai perusahaan pada perusahaan Sub Sektor Kimia yang terdaftar di Bursa Efek Indonesia pada periode 2014 - 2018.

Bagi peneliti selanjutnya, disarankan hasil penelitian ini dapat dijadikan salah satu referensi maupun sumber yang terkait dalam sub sektor kimia dan berguna untuk penelitian selanjutnya. Agar hasil penelitian yang didapat lebih memperluas pemahaman dan lebih lengkap lagi. Penelitian juga sangat diharapkan mampu untuk menambah variabel lain yang dapat mempengaruhi nilai perusahaan tersebut, dan dapat memperpanjang periode penelitian agar dapat memperoleh hasil penelitian yang lebih baik lagi.

\section{DAFTAR PUSTAKA}

Amalia, Topo, et all, 2015. Pengaruh Ukuran Perusahaan, Profitabilitas, Struktur Modal dan Keputusan Investasi Terhadap Nilai Perusahaan (Studi Pada Perusahaan Sektor Properti, Real Estate, dan Building Construction yang Terdaftar di Bursa Efek Indonesia (BEI) periode 2010-2013), Jurnal Administrasi Bisnis (JAB), Vol. 23 N0. 2, Juni 2015.

Fahmi, Irham, 2011. Analisis Kinerja Keuangan, Bandung: ALFABETA, CV.

Ghozali, Imam, 2018. Aplikasi Analisis Multivariate Dengan Program IBM SPSS 25, Badan Penerbit Universitas Diponegoro, Semarang.

Hery, 2017. Kajian Riset Akuntansi, PT. Grasindo, Jakarta.

Husnan, Suad, 2015. Dasar-Dasar Manajemen Keuangan, Edisi Kelima. Yogyakarta:BPFE.

I Gusti Ngurah Gede Rudangga, Gede Merta Sudiarta. 2016. Pengaruh Ukuran Perusahaan, Leverage, dan Profitabilitas terhadap Nilai Perusahaan, E-Jurnal Manajemen Unud, Vol. 5 No. 7, 2016: 4394-4422, ISSN: 2302-8912.

Ida Ayu Anggawulan Saraswathi, I Gst. Bgs. Wiksuana, et all, 2016. Pengaruh Risiko Bisnis, Pertumbuhan Perusahaan dan Struktur Modal Terhadap Profitabilitas Serta Nilai Perusahaan Manufaktur, E-Jurnal Ekonomi dan Bisnis Universitas Udayana 5.6, 2016, ISSN: 2337-3067.

Mawar Sharon R. Pantow, Sri Murni, et all, 2015. ANALISA PERTUMBUHAN PENJUALAN, UKURAN PERUSAHAAN, RETURN ON ASSET, DAN STRUKTUR MODAL TERHADAP NILAI PERUSAHAAN YANG TERCATAT 
DI INDEKS LQ 45. Jurnal Emba, Vol.3 No. 1 Maret 2015, hal.961-971, Maret 2015, ISSN: 2303-1174.

Ni Luh Putu Wiagustini, Ni Putu Pertamawati. 2015. PENGARUH RISIKO BISNIS DAN UKURAN PERUSAHAAN PADA STRUKTUR MODAL DAN NILAI PERUSAHAAN PADA PERUSAHAAN FARMASI DI BURSA EFEK

INDONESIA. Jurnal Manajemen, Strategi Bisnis dan Kewirausahaan, Vol. 9 N0. 2, Agustus 2015.

Octavia Languju, Maryam Mangantar, et all, 2016. Pengaruh Return On Equity, Ukuran Perusahaan, Price Earning Ratio, dan Struktur Modal Terhadap Nilai Perusahaan Property and Real Estate Terdaftar Di Bursa Efek Indonesia, Jurnal Berkala Ilmiah Efisiensi, Vol. 16 No. 02, 2016.

Regina, Maryam, et all, 2015. Struktur Modal, Ukuran Perusahaan dan Risiko Perusahaan Terhadap Nilai Perusahaan pada Sub Sektor Plastik dan Pengemasan di BEI. Jurnal EMBA, Vol.3 No.3 Sept Hal 159-169. Sept 2015. Issn : 2303-11.

Rustam,2017. Manajemen Risiko, Jakarta Selatan : Salemba Empat.

Sanusi, Anwar, 2017. Metodologi Penelitian Bisnis, Salemba Empat, Jakarta.

Ta'dir, Parengkuan, et all, 2014. Struktur Modal, Ukuran Perusahaan, dan Risiko Perusahaan terhadap Nilai Perusahaan Otomotif yang Terdaftar di BEI. Jurnal EMBA, Vol 2 No. 2 Juni Hal 879-889. Juni 2014. Issn : 2303-1174. 